\title{
Class Discussion and Class Participation: Determination of Their Relationship
}

\author{
Leah Li Echiverri \\ Wenzhou-Kean University \\ Shang Haoyu \\ Wenzhou-Kean University \\ Xu Keer \\ Wenzhou-Kean University
}

Class discussion as an instructional strategy is placed at the heart of the classroom learning experiences to elicit active student participation. Convenience sampling of 105 undergraduates, majority of which are English as a Second Language (ESL) learners at Wenzhou Kean University (WKU) in China, participated in this descriptive correlational online survey. Findings showed a strong and positive relationship between class discussion and class participation. When there is enough time given for a group of three to five students to discuss general and creative topics on discussion questions given by instructors, the students are more confident to actively participate in class.

Keywords: class discussion, class participation, length of discussion, structure of question, self confidence, instructors' attitudes

\section{INTRODUCTION}

To facilitate ESL learners' immersion in the English learning environment at WKU, class discussion is one of the instructional strategies used by educational practitioners not only to increasingly encourage students' classroom participation but also to implicitly address the global reputation of "Passive Asian Learners" (Echiverri, 2020). Engaging students in discussion is often difficult partly because some students have poor communication skills, short attention spans, desire for relevance, and high need for external stimuli (Elmore, 2013 as cited in Kornfield \& Noack, 2017). When the instructor stops lecturing and allow students to discuss the course focused task, student's thinking skills and their communication skills in the English language are developed (Echiverri). Additionally, students gain understanding during discussion from the shared information or simply from peer influence of knowledgeable students (Smith, et. al., 2009).

However, many students at WKU are observed to be inactive and less engaged in class participation that makes teaching and learning very challenging. Skyfactor Benchworks (2013) reported that first year students' degree of frequency in class participation showed approximately $57 \%$ at high level, $40 \%$ at moderate level and 3\% at the low level. Another study found similar data, showing that students' 
engagement remains approximately low in college classrooms despite evidence that increased participation contributes to better grades (Ahlfeldt, et al., 2005 as cited in Cheatham, et.al., 2017).

Unlike the studies conducted previously, defining differences such as the respondents' profile and educational context are worth noting. In this study, most of the respondents are Chinese ESL learners enrolled in an English Immersion Program. Thus, this study aimed to investigate class discussion solely as a predictor of students' class participation. Examining the correlation between class discussion and class participation among ESL undergraduates is significantly important because it motivates instructors to comprehend the students' attitudes toward the classroom dynamics.

\section{Class Discussion}

Class discussion is defined as an invisible exchange between students and educators with the purpose of improving students' learning and their skills (Witherspoon, et al., 2016). It is very useful when teachers want their students to exchange their ideas and show their understanding of the topic because accordingly class discussion can enhance students' understanding by talking with other classmates, especially in lecture classes (Smith et. al., 2009). In Kornfield and Noack (2017) study, speed-discussion engaged students dynamically, students can remember the central ideas faster, and promotes fuller participation.

Lambert (2015) reported "group size" types as to peer discussion (two students), large group (three to five students) and larger one (more than five students). Brooks and Koretsky (2011) reported that large group size (includes 3 5 students) makes students have more confidence that encourages students' active involvement in class. Sawyer (2014) reported that creative topics can pique students' interest, have more chances to expand their minds because there are less limitations, and have engaged students further in the discussion. According to the study of Dallimore, Hertenstein, and Platt (2004), asking effective questions and giving students' clear direction of the focused topic are suitable for students because they can grasp the "central idea" that makes class discussion more effective.

\section{Class Participation}

Anchored on the principles of constructivism that knowledge is socially constructed and learning is an active process (McLeod, 2019), class participation is a good measure of students' engagement for it requires active student's responses. Class participation, according to Dancer and Kamvounias (2005), can be defined as the extent to which students participate or involve themselves in a class, course, etc. Class participation involves active student responding, which provides students with an opportunity to demonstrate skills learned in the course and allows instructors to provide useful feedback (Heward, 1994, as cited in Cheatham, et.at., 2017)

Three significant factors can influence students' class participation. These are reported as (1) openness and enthusiasm, (2) attitudes and behaviors of students in class, and (3) class formality (Roehling, et. al., 2010). Students were very reluctant to participate in the class when they perceived that the instructors were not open to their divergent opinions and ideas. The Millennial Generation students are highly sensitive to criticism and reluctant to speak if they feel uninformed or are unsure of how their comments will be received. Educational practitioners therefore, need to be consciously aware of the vulnerabilities associated with the Millennial Generation students (Roehling, et. al.)

Students are willing to participate in the class when the class is less formal, for example, described as when instructors are warm when they are called on a first name basis, instead of their last names (Roehling, et. al., 2010). Instructors can show their teaching enthusiasm by showing their eagerness to be involved in a particular subject or activity (Ward, et.al., 2012) to promote class participation. O'Conner (2013) suggested ways to create a comfortable classroom atmosphere such as the students work with teachers to establish the norm of class participation at the beginning of the semester, respecting students' opinions and ideas, and encouraging students to show their learning enthusiasm. In addition, according to the study of Aydin (2013), the results of the correlational analysis showed that classroom participation is found to be positively related to EFL students' self-confidence. 


\section{Conceptual Framework}

\section{FIGURE 1 \\ CONCEPTUAL FRAMEWORK}

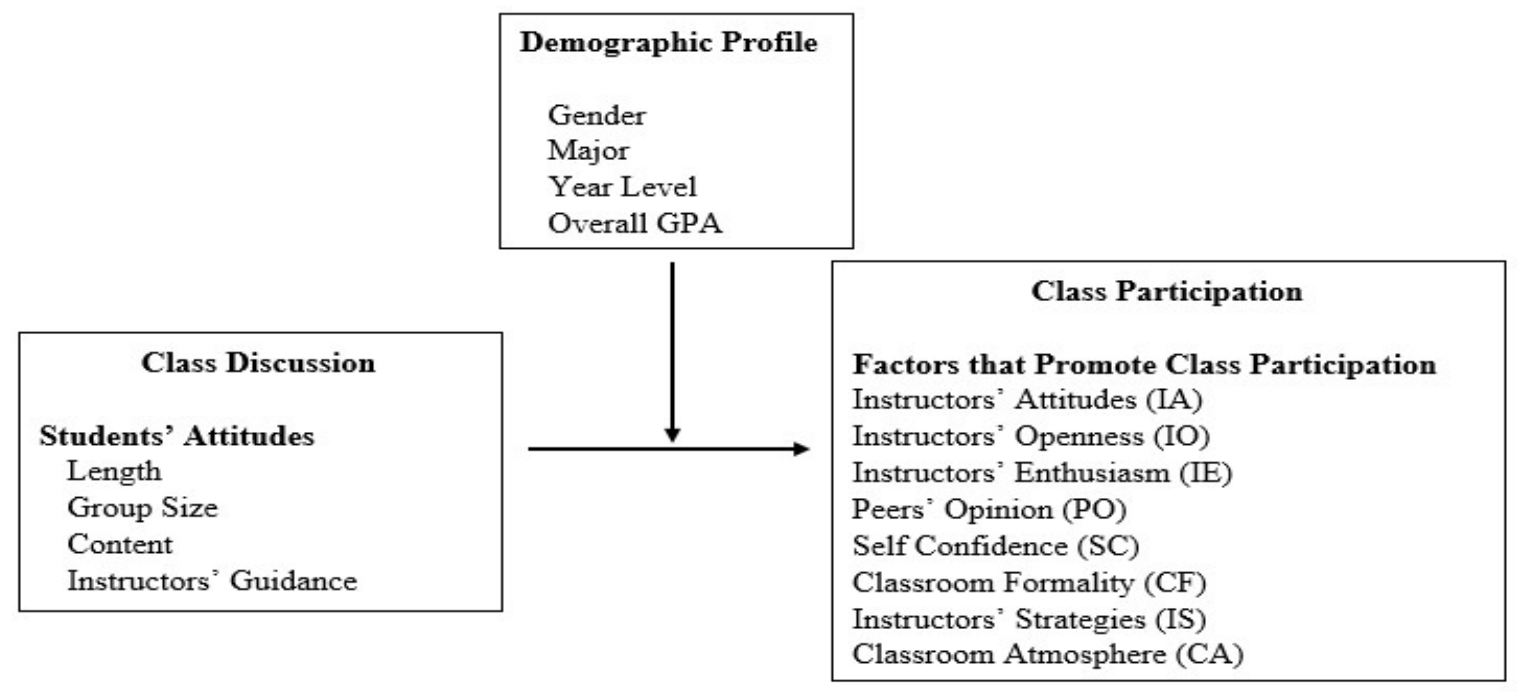

\section{Operational Definition of Terms}

Class Discussion in this study refers to the students' preferred structuring of the components of the interactive activity used by the instructors. The indicators include the length of time given for discussion, size of the grouping, type of content to be discussed, and when to give guidance to students' in terms of giving of course focused task or discussion question.

Class Participation in this study refers to the students' perceptions of the factors that promote them to take part in the class. The factors are instructors' attitudes, instructors' openness, instructors' enthusiasm, peers' opinion, self-confidence, classroom formality, instructors' strategies, and the classroom atmosphere.

\section{METHODOLOGY}

Descriptive-correlational design was used in the study to determine the correlation between class discussion and class participation. The study was conducted at a Sino-Foreign University in China, specifically, Wenzhou-Kean University (WKU). Having the status of a jointly Chinese-American higher educational institution, the English Immersion Program is applied across curricular programs to adopt to the American educational system.

Convenience sampling composed of 105 respondents represented $4 \%$ of the 2019 academic year student population of which majority are Chinese. Online questionnaires posted through the survey website named Wenjuanxing and shared to QQ or WeChat was used in the study. Extensive review of the literature and peer critiquing was used to establish the validity and reliability of the research instrument. A four-point attitudinal Likert scale was applied to describe respondents' attitudes and their preferences. Numbers closer to 1 represented strong disagreement (SD) and numbers closer to 4 represented strong agreement (SA).

\section{RESULTS AND DISCUSSION}

\section{Students' Attitudes Towards Class Discussion}

Table 1 presents the students' attitudes toward class discussion in the aspects of length, group size, content, and structure. For the length of class discussion, students prefer the long-discussion $(\bar{X}=2.51)$, but 
their answers fluctuate greatly. Results showed students preference as follows: for group size, the 3 5 people in a group ranked first $(\bar{X}=2.51)$; for content, the "general and creative content discussion" ranked first ( $\bar{X}=2.97$ ) and second ( $\bar{X}=2.85$ ) respectively. For the structure of discussion, students prefer to discuss when professors give or pose discussion questions $(\bar{X}=2.96)$.

TABLE 1

STUDENTS' ATTITUDES TOWARD CLASS DISCUSSION

\begin{tabular}{|l|l|l|l|l|}
\hline Item No. & Descriptive statements & $\begin{array}{l}\text { Mean } \\
\mathbf{X}\end{array}$ & SD & $\begin{array}{l}\text { Scaled } \\
\text { Response }\end{array}$ \\
\hline 1.1 & I prefer long-discussion. (enough time) & 2.51 & .983 & Agree \\
\hline 1.2 & I prefer short-discussion. (time is limited) & 2.38 & 897 & Disagree \\
\hline 2.1 & I prefer one on one discussion. & 2.41 & 886 & Disagree \\
\hline 2.2 & I prefer 3 5 people in one discussion. & 2.51 & 785 & Agree \\
\hline 2.3 & I prefer 5 10 person in one discussion. & 2.20 & .934 & Disagree \\
\hline 3.1 & I prefer academic discussion. & 1.96 & 842 & Disagree \\
\hline 3.2 & I prefer business discussion. & 2.08 & 749 & Disagree \\
\hline 3.3 & I prefer general discussion. & 2.97 & 859 & Agree \\
\hline 3.4 & I prefer technical discussion. & 1.86 & 789 & Disagree \\
\hline 3.5 & I prefer casual discussion. & 1.96 & 865 & Disagree \\
\hline 3.6 & I prefer creative discussion. & 2.85 & 917 & Agree \\
\hline 4.1 & I prefer professors to put forward questions after discussion. & 2.05 & 801 & Disagree \\
\hline 4.2 & I prefer to discuss when professors ask and pose discussion & 2.96 & 795 & Agree \\
\hline Students' attitudes toward class discussion & & & \\
\hline
\end{tabular}

The results showed the respondents' preference on long discussion described as the giving of enough time when it comes to length of time for discussion. The respondents' class discussion preferences support the findings of Brooks and Koretsky (2011) on large group size (3-5 students); of Sawyer (2014) creative topics for content of discussion; and of Dallimore et. al. (2004) professors asking or posing discussion questions.

\section{The Factors That Influence Students' Class Participation}

Table 2 presents the indicators used to measure the students' perception on the factors that influence students' class participation as follows: "instructors' attitudes", "instructors' openness", and "instructors' enthusiasm"; "peers" opinion"; "self-confidence"; "class formality"; "instructor's strategies"; and "classroom atmosphere".

Among the eight factors, the instructors' attitude $(\bar{X}=3.20)$; class formality $(\bar{X}=3.19)$; and comfortable classroom atmosphere $(\bar{X}=3.19)$ ranked as the high factors that promote in shaping the undergraduates' class participation while the factor of peers' opinion ranked the lowest $(\bar{X}=2.95)$. 
TABLE 2

FACTORS THAT PROMOTE STUDENTS' CLASS PARTICIPATION

\begin{tabular}{|l|l|l|l|l|}
\hline $\begin{array}{l}\text { Item } \\
\text { No. }\end{array}$ & Descriptive statements & Mean X & SD & $\begin{array}{l}\text { Scaled } \\
\text { Response }\end{array}$ \\
\hline 1.1 & I think instructors' attitude influence my class participation & 3.20 & .786 & Agree \\
\hline 1.2 & $\begin{array}{l}\text { I think instructors' openness influences my class } \\
\text { participation }\end{array}$ & 3.16 & .774 & Agree \\
\hline 1.3 & $\begin{array}{l}\text { I think instructors' enthusiasm influences my class } \\
\text { participation }\end{array}$ & 3.10 & .798 & Agree \\
\hline 1.4 & I think peers' opinion influences my class participation & 2.95 & .731 & Agree \\
\hline 1.5 & I think self-confidence influences my class participation & 3.13 & .784 & Agree \\
\hline 1.6 & I think class formality influences my class participation & 3.19 & .752 & Agree \\
\hline 2.1 & $\begin{array}{l}\text { I think useful instructors' strategies can promote class } \\
\text { participation. }\end{array}$ & 3.13 & .773 & Agree \\
\hline 2.2 & $\begin{array}{l}\text { I think a comfortable classroom atmosphere can promote } \\
\text { class participation. }\end{array}$ & 3.19 & .786 & Agree \\
\hline
\end{tabular}

Class Discussion and Class Participation Correlations and Practical Implications

To establish relationships of independent and dependent variables, researchers used Bivariate Correlational analysis as shown in Table 3. Findings showed that there is a strong positive correlation between class discussion and class participation $(r=.674)$ at the .05 level of significance.

When individual dimensions of class discussion and class participation were considered, length and class participation had the highest correlation $(r=.795)$. According to this result, when instructors design class discussion for WKU students who are English as a Second Language (ESL) learners, it is suggested that instructors consider students' preference for length of discussion by giving them enough time to discuss. This implies that allocating longer time for discussion increasingly encourage students to participate in class.

In the same manner, when individual dimensions of class participation and overall class discussion were considered, self-confidence and class discussion had the highest correlation $(r=.727)$. The finding implies that students' self-confidence increases when students are involved in class discussions.

It cannot be ignored that the area on course content $(r=.663)$ and class formality $(r=.534)$ ranked lowest in the correlation between class discussion and class participation. Top priority to address these shortcomings suggest that in the area of course content, when students are engaged in general and creative topics during discussions, the instructors have to manifest openness and enthusiasm. When students perceived that instructors are open and enthusiastic to students' divergent opinions and ideas, students' class participation increases.

Whereas, in the area of class formality, calling students on first name basis and respecting their opinions and ideas regardless of how divergent are these from that of the instructors will create a less formal classroom setting that make students feel more comfortable. The more students feel comfortable in class; the more students are involved in class discussion.

When it comes to the correlation of class discussion and class participation, specifically in the area of group size $(r=.673)$ and structure $(r=.679)$, the findings suggest that students' grouping of three to five whereby instructors' provide guidance by asking or posing questions or giving directions on the focused task increasingly encourage students' class participation. 


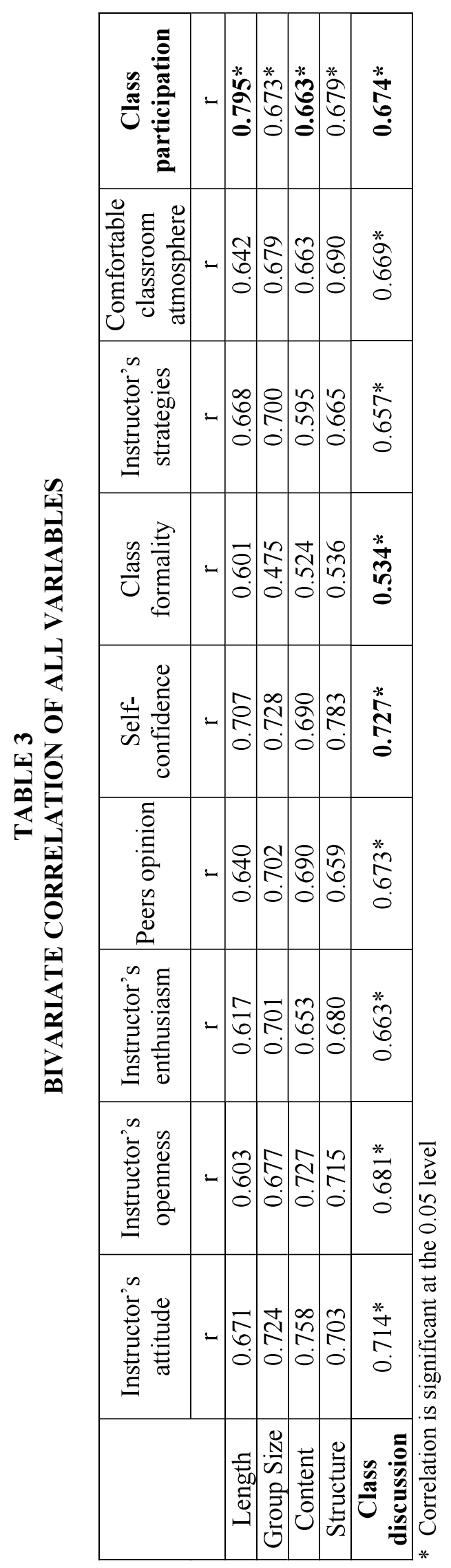

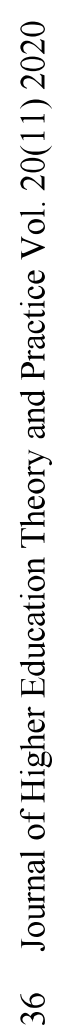




\section{CONCLUSIONS AND RECOMMENDATIONS}

The study established the following relationships between class discussion and class participation as follows: First, allocating longer time for discussion encourages students to participate in class; Second, students' self-confidence increases when students are involved in class discussion; Third, instructors' openness and enthusiasm to students' divergent opinions and ideas increase students' class participation; Fourth, when students feel comfortable in class, the more students get involve in class discussion; Lastly, group composition of three to five students and active facilitation of instructors during class discussion increasingly encourage students' class participation.

Taking into account that the subjects of the study are mostly Chinese-ESL learners enrolled in university programs in which English is the medium of instruction, the following instructional techniques are thereby recommended:

A. Provide enough time for class discussion;

B. Organize the group size composition to include only three to five students;

C. Give discussion questions during group breakout;

D. Introduce more general and creative topics for class discussion;

E. Instructors' should manifest attitudes of openness and enthusiasm to students' divergent opinions and ideas;

F. Call students on a first name basis to create a more comfortable and less formal classroom atmosphere.

\section{REFERENCES}

Ahlfeldt, S., Mehta, S., \& Sellnow, T. (2005). Measurement and analysis of student engagement in university classes where varying levels of PBL methods of instruction are in use. Higher Education Research \& Development, 24(1), 5-20.

Aydin, S. (2013). Teachers' perceptions about the use of computers in EFL teaching and. learning: The case of Turkey. Computer Assisted Language Learning, 26(3), 214-233.

Brooks, B.J., \& Koretsky, M.D. (2011). The influence of group discussion on students' responses and confidence during peer instruction. Journal of Chemical Education, 88(11), 1477-1484.

Bruski, M. (2019). The Power of Classroom Discussion. Retrieved from https://www.seedpaknwboces.org/article/power-classroom-discussion

Cheatham, J., Ozga, J., St.Peter, C., Mesches, G., \& Owsiany, J. (2017). Increasing class participation in college classrooms with the good behavior game. Journal of Behavioral Education, 26(3), 277292. DOI 10.1007/s10864-017-9266-7

Dallimore, E.J., Hertenstein, J.H., \& Platt, M.B. (2004). Classroom participation and discussion effectiveness: Student-generated strategies. Communication Education, 53(1). DOI: $10.1080 / 0363452032000135805$

Dancer, D., \& Kamvounias, P. (2005). Student involvement in assessment: A project. designed to assess class participation fairly and reliably. Assessment \& Evaluation in Higher Education, 30(4), 445454.

Echiverri, L. (2020). Classroom learning motivators: Breaking ESL university students' passivity in class discussion. DOI: http://dx.doi.org/10.4995/HEAd20.2020.11098

Kornfield, S., \& Noack, K. (2017). Speed-discussion: Engaging students in class discussions. Communication Teacher, 31(3), 162-166

Lambert, J. (2015). Class discussion and one-to-one interaction: Their effect on the decisions of fourthgraders to write. The Journal of Educational Research, 78(5), 315-318.

McLeod, S. (2019). Constructivism as theory for teaching and learning. Simply Psychology.

O'Connor, K. (2013). Class participation: Promoting in-class student. engagement. Education, 133(3), 340-344. 
Roehling, P., Vander Kooi, T., Dykema, S., Quisenberry, B., \& Vandlen, C. (2010). Engaging the millennial generation in class discussions. College Teaching, 59(1), 1-6.

DOI: $10.1080 / 87567555.2010 .484035$

Sawyer, R.K. (2004). Creative teaching: Collaborative discussion as disciplined improvisation. Educational Researcher, 33(2), 12-20.

Skyfactor Benchworks. (2013). For First-Year students, how does class participation relate to other academic behaviors and outcomes? Retrieved October 2, 2020, from https://www.skyfactor.com/wp-content/uploads/2015/03/For-First-Year-Students-HowDoes-Class-Participation-Relate-to-Other-Academic-Behaviors-and-Outcomes.pdf

Smith, M., Wood, W., Adams, W., Wieman, C., Knight, J., Guild, N., \& Su, T. (2009). Why peer discussion improves student performance on in-class concept questions. Science, 323(5910), 122124. DOI: $10.1126 /$ science. 1165919

Ward, J., Cody, J., Schaal, M., \& Hojat, M. (2012). The empathy enigma: an empirical. study of decline in empathy among undergraduate nursing students. Journal of Professional Nursing, 28(1), 3440.

Witherspoon, M., Sykes, G., \& Bell, C. (2016). Leading a Classroom Discussion: Definition, supportive evidence, and measurement of the ETS ${ }^{\circledR}$ National Observational Teaching Examination (NOTE) assessment series (Research Memorandum No. RM-16-09). Princeton, NJ: Educational Testing Service. 